\title{
JENIS-JENIS SANKSI PIDANA YANG DAPAT DITERAPKAN TERHADAP KORPORASI
}

\author{
Kristian $^{1}$
}

\begin{abstract}
With the acceptance of the corporation as the subject of criminal law that was considered to be of a criminal act and criminally accountable for his actions, will cause some consequences that could potentially cause problems in its application. These problems are related to the type of criminal sanctions such as what can be applied to the corporation. This article will discuss three main issues related to the questions get the death penalty and imprisonment applied to the corporation ?; with respect to the formulation of criminal sanctions for corporate formulated single and associated with other criminal sanctions or right what can be imposed against a corporation?)
\end{abstract}

Keywords: criminal law, corporate criminal offenses, criminal sanctions for corporate

\begin{abstract}
Abstrak
Dengan diterimanya korporasi sebagai subjek hukum pidana yang dinilai dapat melakukan tindak pidana dan mempertanggungjawabkan perbuatannya secara pidana, akan menimbulkan beberapa konsekuensi yang berpotensi menimbulkan permasalahan dalam penerapannya. Permasalahan tersebut adalah berkaitan dengan jenis sanksi pidana seperti apa yang dapat diterapkan terhadap korporasi. Dalam tulisan ini akan dibahas 3 masalah utama yaitu berkaitan dengan pertanyaan dapatkan pidana mati dan pidana penjara diterapkan terhadap korporasi?; berkenaan dengan perumusan sanksi pidana bagi korporasi yang dirumuskan secara tunggal dan berkaitan dengan sanksi pidana lain apa yang dapat atau tepat dijatuhkan terhadap suatu korporasi?)
\end{abstract}

Kata Kunci: hukum pidana, tindak pidana korporasi, sanksi pidana bagi korporasi

\section{Pengantar}

Dengan diterimanya korporasi sebagai subjek hukum pidana yang dinilai dapat melakukan tindak pidana dan mempertanggungjawabkan perbuatannya secara pidana, sudah tentu akan menimbulkan suatu konsekuensi lebih lanjut

\footnotetext{
${ }^{1}$ Mahasiswa Program Pasca Sarjana Program Magister Ilmu Hukum (S2) Universitas Katolik Parahyangan (UNPAR) Bandung.
} 
yaitu berkaitan dengan pidana dan pemidanaan bagi korporasi. Dengan perkataan lain, dapat dikatakan bahwa apakah sanksi pidana tepat apabila diterapkan terhadap suatu korporasi? Apabila dinilai tepat, sanksi pidana seperti apa yang dapat dijatuhkan terhadap korporasi sebagai bentuk pertanggungjawaban atas perbuatannya? Menurut H. Setiyono, dalam bukunya berjudul Kejahatan Korporasi Analisis Viktimologi Dan Pertanggungjawaban Korporasi Dalam Hukum Pidana menyatakan bahwa pemidanaan merupakan salah satu sarana untuk menanggulangi masalah-masalah sosial dalam mencapai tujuan yaitu kesejahteraan masyarakat. Oleh sebab itu, dengan penggunaan sanksi yang berupa sanksi pidana terhadap kejahatan korporasi yang penuh motif ekonomi harus dipertimbangkan benar urgensinya. ${ }^{2}$

Terkait dengan penjatuhan sanksi pidana bagi suatu korporasi ini, penulis pertama-tama akan mengutip terlebih dahulu pendapat dari Clinard dan Yeagar yang menyatakan bahwa penjatuhan sanksi pidana terhadap suatu korporasi haruslah memenuhi kriteria-kriteria tertentu, dan apabila kriteriakriteria tertentu tersebut tidak terpenuhi maka sebaiknya sanksi perdatalah yang digunakan. Adapun kriteria-kriteria yang dikemukakan oleh Clinard dan Yeagar tersebut adalah sebagai berikut: ${ }^{3}$

a. The Degree Of Loss To The Public. (Derajat kerugian terhadap publik);

b. The Lever Of Complicity By High Corporate Managers. (Tingkat keterlibatan oleh jajaran manager suatu korporasi);

c. The Duration of The Violation. (Lamanya pelanggaran yang dilakukan oleh korporasi);

d. The Frequensi Of The Violation By The Corporation. (Frekuensi pelanggaran yang telah dilakukan oleh korporasi);

e. Evidence Of Intent To Violate. (Alat bukti yang dimaksudkan untuk melakukan pelanggaran);

f. Evidence Of Extortion, As In Bribery Cases. (Alat bukti dalam kasus pemerasan atau kasus-kasus suap);

g. The Degree Of Notoriety Engendered By The Media. (Derajat pengetahuan publik tentang hal-hal negatif yang ditimbulkan oleh pemberitaan media);

h. Precedent In Law. (Yurisprudensi);

i. The History Of Serious, Violation By The Corporation. (Riwayat pelanggaran-pelanggaran serius yang pernah dilakukan oleh korporasi);

j. Deterence Potential. (Kemungkinan pencegahan);

k. The Degree Of Cooperation Evinced By The Corporation. (Derajat kerja sama yang ditunjukkan oleh korporasi yang melakukan tindak pidana).

${ }^{2}$ H. Setiyono, "Kejahatan Korporasi Analisis Viktimologi Dan Pertanggungjawaban Korporasi Dalam Hukum Pidana”, Edisi kedua Cetakan pertama, (Malang: Banymedia Publishing, 2003), hal. 116-117.

\footnotetext{
${ }^{3}$ Muladi dan Dwidja Priyatno, "Pertanggungjawaban Korporasi Dalam Hukum Pidana", (Bandung: STHB, 1991), hal. 118.
} 
Sehubungan dengan hal tersebut diatas maka perlu pula untuk mempertimbangkan peringatan atau pendapat dari Sudarto yang menyatakan bahwa sanksi pidana akan menemui kegagalan dan hanya akan mendatangkan kecemasan belaka. Dalam hal ini, apabila terlalu banyak menggunakan ancaman pidana dapat mengakibatkan devaluasi dari undang-undang pidana itu sendiri. ${ }^{4}$ Selain itu, sehubungan dengan sanksi pidana ini, Jeremy Bentham, menyatakan hal yang serupa dimana ia menyatakan bahwa sanksi pidana jangan digunakan apabila groundless (tanpa dasar), needless (tidak berguna), unprofitable (tidak mendatangkan keuntungan), dan ineffective (tidak efektiv). ${ }^{5}$ Demikian juga dengan Packer yang menyatakan hal serupa dimana ia menyatakan bahwa sanksi pidana akan menjadi penjamin yang utama apabila digunakan dengan cermat, dengan hati-hati dan digunakan secara manusiawi. Akan tetapi sebaliknya, sanksi pidana akan menjadi pengancam yang membahayakan apabila digunakan secara Indiscriminately (diskriminasi) dan coercively (dengan paksaan).

Oleh karena itu, lebih lanjut Packer menegaskan bahwa syarat-syarat penggunaan sanksi pidana secara optimal harus mencakup hal-hal sebagai berikut: ${ }^{6}$

a. Perbuatan yang dilarang tersebut menurut pandangan sebagian besar anggota masyarakat secara menyolok dianggap membahayakan masyarakat dan tidak dibenarkan oleh apa saja yang oleh masyarakat dianggap penting;

b. Penerapan sanksi pidana terhadap perbuatan tersebut konsisten dengan tujuan-tujuan pemidanaan;

c. Pemberantasan terhadap perbuatan tersebut tidak akan menghalangi atau merintangi perilaku masyarakat yang diinginkan;

d. Perilaku tersebut dapat dihadapi melalui cara yang tidak berat sebelah dan tidak bersifat diskriminatif;

e. Pengaturan melalui proses hukum pidana tidak akan memberikan kesan memperberat baik secara kualitatif maupun secara kuantitatif;

f. Tidak ada pilihan-pilihan yang beralasan daripada sanksi pidana tersebut guna menghadapi perilaku yang bersangkutan.

Dari berbagai pendapat sebagaimana disebutkan diatas, dapat disimpulkan bahwa pidana hendaknya digunakan apabila memang benar-benar mendasar dan apabila benar-benar dibutuhkan. Dan pidana itu akan bermanfaat apabila digunakan secara cermat, secara hati-hati, dan secara manusiawi serta digunakan dalam waktu yang tepat dan keadaan yang tepat pula. Sebaliknya, mengutip kembali pendapat dari Sudarto, Jeremy Bentham, Packer, Clinard

\footnotetext{
${ }^{4}$ H. Setiyono, Op. Cit., hal, 117.

${ }^{5}$ Ibid.

${ }^{6}$ Ibid.
} 
dan Yeagar diatas, apabila penggunaan pidana tersebut tidak benar, tidak tepat, tidak cermat, tidak hati-hati dan digunakan dengan tidak manusiawi atau digunakan secara "sembarangan" akan membahayakan atau akan menjadi pengancam yang utama.

Oleh sebab itu, mengutip kembali pertanyaan yang sudah dikemukakan diatas, apakah penjatuhan pidana bagi korporasi dalam hukum Indonesia (tepatnya dalam hkum pidana Indonesia) sudah tepat? Apabila dinilai sudah tepat, sanksi pidana seperti apa yang dapat diterapkan terhadap suatu korporasi yang melakukan suatu tindak pidana? Untuk menjawab pertanyaan ini memang membutuhkan pengkajian yang mendalam.

Namun sebelum membahas masalah tersebut, pertanyaan dasar yang muncul adalah, apakah terdapat urgensi untuk menjadikan korporasi sebagai subjek hukum pidana yang menilai korporasi sebagai pihak yang dapat melakukan suatu tindak pidana dan mempertanggungjawabkan perbuatannya secara pidana? Terkait dengan hal ini, apabila dilihat dari dasar pertimbangan pemidanaan korporasi menurut Tim Pengkajian Bidang Hukum Pidana tepatnya dalam laporan hasil Pengkajian Bidang Hukum tahun 1980-1981 menyatakan bahwa:

Jika dipidananya pengurus saja tidak cukup untuk mengadakan represi terhadap delik-delik (tindak pidana) yang dilakukan oleh atau dengan suatu korporasi karena delik itu cukup besar atau kerugian yang ditimbulkan dalam masyarakat atau saingansaingannya sangat berarti. ${ }^{7}$

Dengan melihat dasar pertimbangan Tim Pengkajian Bidang Hukum Pidana dalam laporannya sebagaimana dikemukakan diatas, menyatakan bahwa dengan dipidananya pengurus saja tidak dapat memberikan jaminan yang cukup bahwa korporasi tidak akan sekali lagi melakukan perbuatan yang dilarang oleh undang-undang, oleh sebab itu, terdapat urgensi untuk menjatuhkan pidana bagi korporasi atau dengan perkataan lain, terdapat urgensi mengatur korporasi sebagai subjek hukum pidana yang dinilai dapat melakukan suatu tindak pidana dan mempertanggungjawabkan perbuatannya secara pidana pula. Selain itu, perlu pula dikemukakan bahwa pemidanaan korporasi tidak dapat dilakukan secara sembarangan melainkan harus didasarkan kepada tujuan pemidanaan baik yang bersifat preventif (khusus) maupun yang bersifat represif. ${ }^{8}$

\footnotetext{
${ }^{7}$ Ibid.

${ }^{8}$ Ibid.
} 


\section{Rumusan Masalah}

Sebagai konsekuensi lebih lanjut, muncul beberapa masalah hukum sebagaimana yang akan dibahas dalam tulisan ini. Masalah pertama adalah berkenaan dengan dapatkan sanksi pidana berupa pidana mati dan pidana penjara diterapkan terhadap korporasi? Masalah kedua adalah berkaitan dengan perumusan sanksi pidana bagi korporasi yang dirumuskan secara tunggal atau dengan perkataan lain tidak ada alternatif sanksi lain yang dapat dibebankan terhadap korporasi. Hal ini tentunya akan menjadi suatu permasalahan manakala sanksi pidana tersebut (pidana denda) tidak dibayar oleh korporasi. Masalah ketiga adalah berkaitan dengan sanksi pidana seperti apa yang dapat atau tepat dijatuhkan terhadap suatu korporasi? Hal ini menurut hemat penulis akan menjadi suatu permasalahan tersendiri dalam penerapannya mengingat tidak semua tindak pidana dapat dilakukan oleh korporasi dan tidak semua sanksi pidana sebagaimana diatur atau dirumuskan dalam pasal 10 KUHP dapat dikenakan terhadap korporasi.

Untuk menjawab ketiga masalah tersebut, akan diuraikan dalam dua bagian. Terkait dengan permasalahan pertama akan diuraikan dalam satu bagian tersendiri sedangkan permasalahan kedua dan ketiga, akan diuraikan dalam satu bagian berikutnya.

\section{Penjatuhan Pidana Mati Dan Pidana Penjara Bagi Korporasi}

Untuk menjawab permasalahan pertama berkaitan dengan dapatkan sanksi pidana berupa pidana mati dan pidana penjara diterapkan terhadap korporasi? pertama-tama penulis akan mengutip pendapat dari Peter Gillies yang menyatakan bahwa: "in most cases the punishment visited upon the corporation will be fine" (dibanyak kasus, pidana yang dapat dijatuhkan terhadap suatu korporasi hanyalah pidana denda).

Hal senada juga dikemukakan oleh Loebby Loqman yang menyatakan bahwa:

Tidak semua jenis pidana yang terdapat didalam peraturan perundang-undangan pidana dapat diterapkan terhadap korporasi. Pidana mati, pidana penjara dan pidana kurungan pada dasarnya tidak dapat dijatuhkan pada korporasi. Yang mungkin dijatuhkan pada korporasi adalah pidana denda. Namun demikian, selain pidana denda juga terhadap korporasi dapat diberikan tindakan untuk memulihkan keadaan seperti sebelum adanya kerusakan oleh suatu perusahaan. Sesuai dengan perkembangannya, ganti rugi juga dapat dijatuhkan pada korporasi sebagai jenis pidana baru.

\footnotetext{
${ }^{9}$ Peter gillies, (Penyunting: Barda Nawawi Arief), “Criminal Law”, (Tanpa kota, tanpa penerbit, 1990), hal. 125.
} 
Ganti kerugian ini dapat berupa ganti kerugian terhadap korban, dapat pula berupa pengganti kerusakan yang telah ditimbulkan. ${ }^{10}$

Dalam perkembangan mutakhir, sanksi pidana sebagaimana dikemukakan diatas (pidana denda dan pidana ganti kerugian dalam rangka pemulihan dampak kejahatan) dinilai tidak sebanding dengan akibat yang ditimbulkan oleh tindak pidana korporasi dan dinilai tidak dapat mencegah dilakukannya tindak pidana yang serupa baik oleh korporasi yang bersangkutan ataupun oleh korporasi yang lainnya. Oleh sebab itu, penulis ingin mencoba mengangkat jenis sanksi lain yang dinilai efektif dan evisien untuk diterapkan terhadap korporasi. Sanksi tersebut adalah penjatuhan pidana mati dan pidana penjara bagi suatu korporasi dan perampasan asset tindak pidana.

Terkait dengan jenis sanksi pidana yang pertama, penulis akan mengutip terlebih dahulu pendapat dari Brickey yang menyatakan bahwa pada umumnya, pidana pokok yang dapat dijatuhkan pada suatu korporasi hanyalah pidana denda (fine), seperti pendapat Peter Gillies dan pendapat Loebby Loqman diatas. Akan tetapi, apabila dengan dijatuhkannya sanksi berupa penutupan seluruh korporasi, maka pada dasarnya merupakan "corporate death penalty", sedangkan sanksi berupa segala bentuk pembatasan terhadap aktivitas korporasi, maka sebenarnya mempunyai hakekat sama dengan pidana penjara atau pidana kurungan, sehingga dikenal ada istilah "corporate imprisonment". Dan pidana tambahan berupa pengumuman keputusan hakim (publication) merupakan sanksi yang paling ditakuti oleh korporasi. ${ }^{11}$

Terkait dengan "corporate death penalty" sebagaimana dikemukakan oleh Brickey diatas baik yang dilakukan secara keseluruhan ataupun yang dilakukan secara sebagian, menurut Yoshio Suzuki, hal ini harus dilakukan secara sangat hati-hati oleh karena dampak putusan dari "corporate death penalty" tersebut sangat luas, dalam hal ini yang menderita tidak hanya pihak yang berbuat salah, tetapi juga akan berdampak bagi orang-orang yang tidak berdosa seperti buruh, pemegang saham dan para konsumen sebuah pabrik. ${ }^{12}$

Apabila dibandingkan dengan stelsel pemidanaan yang ada dalam hukum pidana Indonesia, tepatnya dalam KUHP yang berlaku dewasa ini, Perlu dikemukakan dimuka bahwa korporasi tidak dikenal sebagai subjek hukum pidana karena dalam KHUP yang berlaku dewasa ini sangat dipengaruhi oleh asas "societas delinquere non potest" yaitu badan hukum (korporasi) tidak dapat melakukan tindak pidana. ${ }^{13}$ Namun demikian, didalam undang-undang yang tersebar diluar KUHP (hukum pidana khusus) telah diatur korporasi

${ }^{10}$ Lobby Loqman, "Kapita Selekta Tindak Pidana Dibidang Perekonomian”, (Jakarta: Dtacom, 2002), hal 34-35.

11 Muladi dan Barda Nawawi Arief, "Bunga Rampai Hukum Pidana", (Bandung: Alumni, 2007), hal. 35.

\footnotetext{
${ }^{12}$ Muladi dan DwijaPriyatno, Op. Cit. hal. 115.

${ }^{13}$ Ibid., hal. 53 .
} 
sebagai subjek hukum pidana. Hal ini menunjukan pula bahwa terdapat urgensi untuk mengatur korporasi sebagai subjek hukum pidana dan dalam rangka menghindari dualisme norma atau tumpang tindih aturan diantara peraturan perundang-undangan yang tersebar diluar KUHP dan akan menimbulkan ketidakpastian hukum, maka menurut hemat penulis, pengaturan korporasi sebagai subjek hukum pidana seharusnya diatur dalam buku I KUHP sehingga akan berlaku bagi seluruh tidak pidana (baik yang diatur dalam KUHP maupun yang diatur diluar KUHP). Selain itu, dalam merumuskan sanksi pidana didalam KUHP dikenal dengan sistem dua jalur (double track system) yaitu sebuah stelsel pemidanaan disamping penjatuhan sanksi pidana dikenal juga tindakan yang dapat dikenakan kepada pelaku tindak pidana. Hal ini diatur secara tegas dalam pasal 10 KUHP yang berbunyi:

Pidana terdiri atas:

a. Pidana Pokok:

1. Pidana Mati;

2. Pidana Penjara;

3. Kurungan;

4. Denda;

5. Pidana Tutupan (berdasarkan Undang-Undang Nomor 20 Tahun 1946 Berita RI II Nomor 247)

b. Pidana Tambahan :

1. Pencabutan Hak-Hak Tertentu;

2. Perampasan Barang-Barang Tertentu;

3. Pengumuman Keputusan Hakim.

Dari ketentuan pidana diatas dapat dilihat dengan jelas bahwa semua sanksi tersebut hanya ditujukan atau hanya dapat diterapkan pada manusia alamiah (naturlijk person), sedangkan sanksi yang dapat dikenakan pada korporasi hanyalah denda dan pengumuman putusan hakim. Hal ini merupakan hal yang wajar disebabkan karena KUHP tidak mengenal korporasi sebagai subjek hukum. Lain halnya dengan undang-undang yang tersebar diluar KUHP atau yang dikenal dengan hukum pidana khusus, dalam hukum pidana khusus ini sudah dengan tegas menyatakan bahwa korporasi sebagai salah satu subjek hukum pidana. Salah satu Undang-Undang khusus yang menyatakan dengan tegas bahwa korporasi sebagai subjek hukum adalah Undang-Undang Tindak Pidana Ekonomi yaitu Undang-Undang Nomor 7 Drt tahun1955. Dalam pasal 15 ayat (2) Undang-Undang ini dinyatakan bahwa:

Suatu tindak pidana ekonomi dilakukan juga oleh suatu, atas nama suatu badan hukum, suatu perseroan, suatu perserikatan orang, atau suatu yayasan, jika tindakan dilakukan oleh orang-orang baik berdasarkan hubungan kerja maupun hubungan lain, bertindak dalam lingkungan badan hukum, perseroan, perserikatan atau yayasan itu tidak peduli apakah orang-orang itu masing-masing tersendiri melakukan tindak pidana ekonomi itu atau pada mereka bersama-sama ada anasir-anasir tindak pidana tersebut. 
Sedangkan terkait dengan perumusan sanksi pidana dan tindakan yang dapat dijatuhkan baik terhadap manusia alamiah (naturlijk person) ataupun bagi suatu korporasi dinyatakan sebagai berikut:

a. Hukuman Pokok Berupa :

1. Hukuman Penjara;

2. Hukuman Kurungan;

3. Denda.

b. Hukuman Tambahan Berupa :

1. Pencabutan Hak-Hak Tersebut Dalam Pasal 35 KUHP;

2. Penutupan Seluruhnya Atau Sebagian Perusahan Terhukum Dimana Tindak Pidana Ekonomi Itu Dilakukan Selama 1 (Satu) Tahun;

3. Perampasan Barang-Barang Tetap Yang Berwujud Atau Tidak Berwujud:

3.1 Dengan Mana Atau Mengenai Mana Tindak Pidana Itu Dilakukan

3.2 Yang Sebagian Atau Seluruhnya Diperoleh Dengan Tindak Pidana Itu

3.3 Harga Lawan Yang Menggantikan Barang Itu; Tanpa Memperhatikan Apakah Barang Atau Harga Lawan Tersebut Milik Si Terhukum Atau Bukan Miliknya.

4. Perampasan Barang-Barang Tidak Tetap Yang Berwujud Atau Tidak Berwujud:

a. Yang Termasuk Perusahan Si Terhukum, Dimana Tindak Pidana Itu Dilakukan ;

b. Harga Lawan Yang Menggantikan Barang-Barang Itu; Tanpa Memperdulikan Apakah Barang Atau Harga Lawan Itu Milik Si Terhukum Atau Bukan Miliknya, Akan Tetapi :

- Sekedar Barang-Barang Itu Sejenis Dan Mengenai Tindak Pidananya;

- Bersangkutan Dengan Barang Yang Dapat Dirampas Menurut Ketentuan Tersebut Dalam Pasal 7 Ayat (1) Sub C.

5. Pencabutan Seluruh Atau Sebagian Hak-Hak Tertentu Atau Penghapusan Seluruh Atau Sebagian Keuntungan Tertentu Yang Telah Atau Dapat Diberikan Kepada Si Terhukum Oleh Pemerintah Untuk Waktu Selambat-Lambatnya 2 (Dua) Tahun;

6. Pengumuman Keputusan Hakim.

1. Perampasan:

a. Perampasan Barang-Barang Yang Bukan Kepunyaan Si Terhukum Tidak Dijatuhkan Sekedar Hak-Hak Pihak Ketiga Dengan Itikad Baik Akan Terganggu;

b. Dalam Perampasan Barang-Barang, Maka Hakim Dapat Memerintahkan, Bahwa Seluruhnya Atau Sebagian Akan Diberikan Kepada Si Terhukum.

c. Tindakan Tata Tertib Antara Lain : 
1. Penempatan Perusahan Di Bawah Pengampuan;

2. Kewajiban Membayar Uang Jaminan;

3. Kewajiban Mengerjakan Apa Yang Dilalaikan Tanpa Hak Atau Meniadakan Apa Yang Dilakukan Tanpa Hak;

4. Kewajiban Membayar Sejumlah Uang Sebagai Pencabutan Keuntungan.

Dari kedua bentuk penjatuhan sanksi pidana diatas, dapat dilihat bahwa baik dalam KUHP maupun dalam Undang-Undang Pidana yang bersifat khusus (yang dalam hal ini Undang-Undang Nomor 7 Drt tahun1955 tentang Tindak Pidana Ekonomi maupun Undang-Undang Khusus lainnya seperti Undang-Undang No. 31 tahun 1999 sebagaimana telah diubah oleh UndangUndang No. 20 tahun 2001 tentang Tindak Pidana Korupsi ataupun dalam Undang-Undang No. 8 tahun 2010 tentang Pencegahan dan Pemberantasan Tindak Pidana Pencucian Uang) tidak ditemukan ada istilah "corporate death penalty" ataupun istilah "corporate imprisonment" sebagaimana dikemukakan oleh Brickey diatas. Dalam undang-undang atau hukum positif Indonesia hanya ditemukan istilah "penutupan seluruh atau sebagian korporasi" dan istilah "pencabutan seluruh atau sebagian hak-hak tertentu atau penghapusan seluruh atau sebagian keuntungan tertentu". Oleh sebab itu, muncul sebuah pertanyaan mendasar yaitu: Apakah istilah "corporate death penalty" dan istilah "corporate imprisonment" sama artinya dengan istilah "penutupan seluruh atau sebagian korporasi" dan istilah "pencabutan seluruh atau sebagian hak-hak tertentu atau penghapusan seluruh atau sebagian keuntungan tertentu"? Atau apakah istilah "corporate death penalty" ini pada dasarnya sama dengan Pailit atau Pembubaran perusahaan? Apakah istilah "corporate death penalty" ini hanya merupakan analogi belaka atau memang memiliki perbedaan yang mendasar? Tentu hal ini akan membutuhkan pengkajian lebih lanjut yang tidak dapat dibahas dalam tulisan ini.

Akan tetapi mengenai istilah "corporate death penalty" dan istilah "corporate imprisonment" ini, penulis akan mencoba memberikan perbandingan dengan ketentuan yang ada dalam Undang-Undang No. 31 tahun 1999 sebagaimana telah diubah oleh Undang-Undang No. 20 tahun 2001 tentang Pemberantasan Tindak Pidana Korupsi. Penulis menggunakan UndangUndang No. 31 tahun 1999 sebagaimana telah diubah oleh Undang-Undang No. 20 tahun 2001 tentang Pemberantasan Tindak Pidana Korupsi sebagai perbandingan karena didalam Undang-Undang ini terdapat ketentuan yang secara tegas menyatakan bahwa dalam keadaan tertentu pidana mati dapat dijatuhkan dan terdapat ketentuan yang mengatur mengenai penutupan seluruh atau sebagaian perusahaan dan pencabutan seluruh atau sebagian hak atau keuntungan tertentu yang dapat dijatuhkan baik kepada orang perseorangan maupun terhadap korporasi. Berikut penjelasannya.

Yang dimaksud dengan "setiap orang" dalam Undang-Undang ini adalah "orang perseorangan" dan "korporasi". Hal ini diatur secara tegas dalam pasal 1 angka 3 yang menyatakan bahwa: "Setiap orang adalah orang perseorangan atau termasuk korporasi" sedangkan yang dimaksud dengan korporasi dalam Undang-Undang ini adalah kumpulan orang dan atau kekayaan yang 
terorganisasi baik merupakan badan hukum maupun bukan badan hukum (Pasal 1 angka 1). Kemudian apabila dikaitkan dengan ketentuan pasal 2 ayat (2) yang menyatakan bahwa: “ ... dalam keadaan tertentu, pidana mati dapat dijatuhkan..." maka sebagai konsekuensinya, baik orang perseorangan maupun korporasi dapat dijatuhkan pidana mati. Namun demikian, hal ini tidak serta merta menyatakan bahwa penjatuhan pidana mati dapat diterapkan terhadap korporasi.

Untuk perbandingan tebih lanjut mengenai hal ini, penulis akan mengutip ketentuan sebagaimana dalam pasal 18 ayat (1) poin c dan poin d yang menyatakan bahwa: "Selain pidana tambahan sebagaimana dimaksud dalam Kitab Undang-Undang Hukum Pidana, sebagai pidana tambahan adalah: penutupan seluruh atau sebagian perusahaan untuk waktu paling lama 1 (satu) tahun; pencabutan seluruh atau sebagian hak-hak tertentu atau penghapusan seluruh atau sebagian keuntungan tertentu, yang telah atau dapat diberikan oleh Pemerintah kepada terpidana". Dan didalam pasal 20 (ayat 7) sudah ditentukan secara tegas bahwa: "Pidana pokok yang dapat dijatuhkan terhadap korporasi hanya pidana denda, dengan ketentuan maksimum pidana ditambah 1/3 (satu pertiga)".

Berdasarkan 2 ketentuan tersebut diatas, menurut hemat penulis, pada dasarnya "corporate death penalty" sebagaimana dikemukakan oleh Brickey sama dengan ketentuan "penutupan seluruh atau sebagian perusahaan" dan "corporate imprisonment" pada dasarnya sama dengan ketentuan "pencabutan seluruh atau sebagian hak-hak tertentu atau penghapusan seluruh atau sebagian keuntungan tertentu" sebagaimana diatur dalam pasal 18 ayat (1) poin c dan poin d sebagaimana telah disebutkan diatas. Selain itu, apabila melihat dan mengutip kembali ketentuan dalam pasal 2 ayat (2) yang menyatakan bahwa: "Dalam tindak pidana korupsi sebagaimana dimaksud dalam ayat (1) dilakukan dalam keadaan tertentu, pidana mati dapat dijatuhkan". Dan apabila dilihat dari penjelasannya diatur bahwa: "yang dimaksud dengan "keadaan tertentu" adalah apabila tindak pidana tersebut dilakukan terhadap dana-dana penanggulangan bagi penaggulangan keadaan bahaya, bencana alam nasional, penanggulangan terhadap akibat kerusuhan sosial yang meluas, penanggulangan krisis ekonomi, dan terjadi pengulangan tindak pidana korupsi". Oleh karena itu, menurut hemat penulis, "corporate death penalty" sebagaimana dikemukakan oleh Brickey diatas dapat pula diartikan sebagai penjatuhan pidana mati dalam arti yang sesungguhnya (apabila dikonstruksikan terhadap korporasi akan menjadi penutupan seluruh korporasi) bagi suatu korporasi yang melakukan tindak pidana korupsi dalam keadaan dan terhadap dana-dana penanggulangan bagi penaggulangan keadaan bahaya, bencana alam nasional, penanggulangan terhadap akibat kerusuhan sosial yang meluas, penanggulangan krisis ekonomi, dan terjadi pengulangan tindak pidana korupsi. Selain itu, dengan adanya terminologi "dapat" maka pelaksanaan penjatuhan pidana mati bagi korporasi ini bukan menjadi suatu keharusan melainkan suatu alternatif sanksi. Terkait dengan hal ini, menurut hemat penulis, pengaturan penjatuhan pidana mati bagi korporasi sudah tepat dan dapat dilaksanakan atau diterapkan apabila memang sangat-sangat mendesak 
dan dijatuhkan sebagai pemeberatan atau unsur yang memberatkan pidana (gequaliviceerde).

\section{Perumusan Sanksi Pidana Tunggal Bagi Korporasi Dan Alternatif Sanksi Yang Dapat Dijatuhkan}

Perlu dikemukakan dimuka bahwa terkait dengan permasalahan kedua, yaitu mengenai perumusan sanksi pidana bagi korporasi yang dirumuskan secara tunggal akan muncul manakala pembaca masih berpikiran tradisional dimana tidak mengakui adanya pidana mati dan pidana penjara atau kurungan yang diterapkan terhadap korporasi. Singkatnya, permasalan mengenai perumusan pidana tunggal ini akan muncul manakala pembaca menilai bahwa pidana mati, pidana penjara dan pidana kurungan tidak dapat diterapkan bagi korporasi. Jadi, apabila demikian adanya maka hanya pidana denda yang dapat diterapkan bagi korporasi. Permasalahan tersebut akan tercermin dalam pertanyaan, sanksi pidana lain apakah yang dapat diterapkan terhadap korporasi manakala pidana denda tidak dibayar oleh korporasi? Apabila pidana denda ini dijatuhkan terhadap orang perseorangan (manusia alamiah) tidak akan menimbulkan suatu masalah yang berarti, oleh karena dalam pasal 30 KUHP sudah diatur dengan jelas bagaimana jika denda tidak dibayar "dapat dikenakan pidana kurungan pengganti denda". Sebaliknya, dengan diaturnya korporasi sebagai subjek hukum pidana maka ketentuan semacam ini sudah tentu tidak dapat diterapkan bagi korporasi (selama beranggapan bahwa"corporate death penalty" dan "corporate imprisonment" tidak dapat diterapkan bagi korporasi). Berbeda dengan pandangan yang sudah menilai "corporate imprisonment" atau pidana penjara atau pidana kurungan dapat diterapkan terhadap korporasi maka "corporate imprisonment" yang dalam hal ini adalah "pencabutan seluruh atau sebagian hak-hak tertentu atau penghapusan seluruh atau sebagian keuntungan tertentu" dapat dijadikan alternatif sanksi manakala pidana denda tidak dibayar oleh korporasi.

Singkatnya, apabila pidana denda tidak dibayar oleh korporasi, maka tidak ada sanksi pengganti atau alternatif sanksi lain yang dapat diterapkan terhadap suatu korporasi yang melakukan tindak pidana. Hal ini dikarenakan sampai dengan saat ini tidak ada ketentuan atau hukum yang mengatur mengenai masalah ini. Termasuk pula didalam undang-undang khusus atau hukum pidana khusus seperti Undang-Undang No. 31 tahun 1999 sebagaimana telah diubah oleh Undang-Undang No. 20 tahun 2001 Tentang Pemberantasan Tindak Pidana Korupsi ataupun dalam undang-undang pencucian uang terbaru yaitu Undang-Undang No. 8 tahun 2010 Tentang Pencegahan Dan Pemberantasan Tindak Pidana Pencucian yang tidak diatur alternatif sanksi lain manakala pidana denda tidak dibayar oleh korporasi. Oleh sebab itu, tidaklah berlebihan apabila dikatakan bahwa dalam pengaturan mengenai jenis sanksi pidana yang dapat diterapkan terhadap korporasi mengalami kekosongan hukum (rechtsvacuum).

Demikian pula dengan pidana tambahan berupa pencabutan hak-hak tertentu sesuai dengan ketentuan pasal 10 poin b angka 1 KUHP yang 
mengatur mengenai pencabutak hak-hak tertentu yang penjabarannya diatur dalam Pasal 35 KUHP tidak dapat dikenakan pada korporasi oleh karena hakhak tersebut hanya melekat pada manusia alamiah. Adapun ketentuan pasal 35 KUHP berbunyi:

Hak-hak terpidana yang dapat dicabut dengan putusan hakim dalam hal-hal yang ditentukan dalam kitab undang-undang ini, atau dalam aturan umum yang lain, ialah:

1. Hak memegang jabatan pada umumnya atau jabatan yang tertentu;

2. Hak memasuki Angkatan Bersenjata;

3. Hak memilih dan dipilih dalam pemilihan yang diadakan berdasarkan aturan-aturan umum;

4. Hak menjadi penasihat hukum atau pengurus atas penetapan pengadilan, hak menjadi wali, wali pengawas, pengampu atau pengampu pengawas, atas orang yang bukan anak sendiri;

5. Hak menjalankan kekuasaan bapak, menjalankan perwalian atau pengampuan atas anak sendiri;

Berdasarkan ketentuan diatas dapat dilihat bahwa pencabutan hak memegang jabatan, memasuki Angkatan Bersenjata, memilih dan dipilih dalam pemilihan, menjadi penasihat hukum dan lain sebagainya merupakan hak yang hanya melekat pada manusia alamiah. Oleh sebab itu, ketentuan mengenai pencabutan hak-hak tertentu tidak dapat diterapkan terhadap korporasi karena hak-hak tersebut hanya melekat pada manusia alamiah.

Selain itu, sama dengan pidana tambahan berupa pencabutan hak-hak tertentu sebagaimana dikemukakan diatas, pidana tambahan berupa perampasan barang-barang tertentu sebagaimana diatur dalam pasal 10 poin $\mathrm{b}$ angka 2 tidak dapat diterapkan terhadap korporasi. Hal ini dikarenakan dalam pasal 39 KUHP yang mengatur mengenai perampasan dan penyitaan disebutkan dengan tegas bahwa:

(1) Barang-barang kepunyaan terpidana yang diperoleh dengan kejahatan atau yang dengan sengaja digunakan untuk melakukan kejahatan, dapat dirampas.

(2) Dalam hal pemidanaan karena kejahatan yang dilakukan dengan tidak sengaja atau karena pelanggaran, dapat juga dijatuhkan putusan perampasan berdasarkan hal-hal yang ditentukan dalam undang-undang.

(3) Perampasan dapat dilakukan terhadap orang yang bersalah yang oleh hakim diserahkan kepada pemerintah, tetapi hanya atas barang-barang yang telah disita.

Berdasarkan ketentuan pasal 39 KUHP tersebut, dapat dilihat bahwa perampasan barang hanya dapat dilakukan terhadap barang yang diperoleh dengan kejahatan, barang yang digunakan dalam melakukan kejahatan, barang tersebut harus milik terpidana, hanya terbatas pada benda berwujud dan perampasan hanya dapat dilakukan terhadap barang yang telah disita. 
Ruanglingkup perampasan barang sebagaimana diatur dalamn pasal 39 KUHP tersebut dapat dikategorikan sebagai perampasan yang sempit. Dikatakan demikian karena ruanglingkup perampasan barang sebagaimana diatur dalam pasal 39 sangat sempit dan dalam perkembangannya dewasa ini dinilai tidak cukup dalam rangka mencegah dan memberantas tindak pidana terlebih lagi bagi tindak pidana korporasi. Oleh sebab itu, ketemtuan ini tidak dapat diterpkan terhadap korporasi.

Mengutip kembali pernyataan sebelumnya yang menyatakan bahwa dalam merumuskan sanksi pidana didalam KUHP dikenal dengan sistem dua jalur (double track system) yaitu sebuah stelsel pemidanaan disamping penjatuhan sanksi pidana dikenal juga tindakan yang dapat dikenakan kepada pelaku tindak pidana.

Mengenai tindakan yang dapat dikenakan terhadap pelaku tindak pidana ini, diatur secara tegas dalam pasal 44 ayat (2) KUHP yang berbunyi:

Bila ternyata perbuatan itu tidak dapat dipertanggungkan kepadanya karena pertumbuhan jiwanya cacat atau terganggu karena penyakit, maka hakim dapat memerintahkan supaya orang itu dimasukkan ke rumah sakit jiwa, paling lama satu tahun sebagai masa percobaan" dan dalam pasal 45 yang berbunyi: "...memerintahkan supaya yang bersalah itu dikembalikan kepada orang tuanya, walinya atau pemeliharanya, tanpa dikenakan suatu pidana apa pun; atau memerintahkan supaya yang bersalah itu diserahkan kepada pemerintah tanpa pidana...

Berdasarkan ketentuan tersebut, jelas bahwa semua tindakan sebagaimana diatur dalam pasal 44 ayat (2) dan pasal 45 diatas hanya ditunjukan kepada manusia alamiah dan tidak dapat diterapkan bagi suatu korporasi.

Berdasarkan hal-hal tersebut diatas, dapat disimpulkan bahwa pengaturan atau perumusan sanksi pidana bagi korporasi dirumuskan secara tunggal. Oleh sebab itu, dalam rangka menjawab jenis sanksi pidana lain apa yang dapat diterapkan terhadap korporasi, penulis akan mengutip pendapat yang dikemukakan oleh Suprapto yang menyatakan bahwa hukuman yang dapat dikenakan pada perusahan (dalam hal ini korporasi) adalah: ${ }^{14}$

1. Penutupan seluruhnya atau sebagian perusahan si terhukum untuk waktu tertentu;

2. Pencabutan seluruhnya atau sebagian fasilitas-fasilitas tertentu yang telah atau dapat diperolehnya dari pemerintah oleh perusahan selama waktu tertentu;

3. Penempatan perusahan di bawah pengampuan selama waktu tertentu.

Terkait dengan hal ini, Barda Nawawi Arief menyatakan bahwa: "Di samping pidana denda, sebenarnya terdapat beberapa jenis pidana tambahan

${ }^{14}$ Muladi dan Dwidja Priyatno, Op. Cit., hal. 114. 
dalam Pasal 18 ayat (1) Undang-Undang Nomor 31 Tahun 1999 yang dapat dijadikan pidana pokok untuk korporasi atau setidak-tidaknya sebagai pidana tambahan yang dapat dijatuhkan mandiri. Apabila pidana penjara merupakan pidana pokok untuk "orang", maka pidana pokok yang dapat diidentikkan dengan pidana perampasan kemerdekaan adalah sanksi berupa "penutupan perusahan atau korporasi untuk waktu tertentu" atau "pencabutan hak ijin usaha". 15

Mengutip kembali pendapat Brickey yang mengemukakan bahwa pidana pokok yang dapat dijatuhkan kepada korporasi hanyalah denda (fine), Akan tetapi, apabila dengan dijatuhkannya sanksi berupa penutupan seluruh korporasi, maka pada dasarnya merupakan "corporate death penalty", sedangkan sanksi berupa segala bentuk pembatasan terhadap aktivitas korporasi, maka sebenarnya mempunyai hakekat sama dengan pidana penjara atau pidana kurungan, sehingga dikenal ada istilah "corporate imprisonment". Bahkan pidana tambahan berupa pengumuman keputusan hakim (publication), merupakan sanksi yang sangat ditakuti oleh korporasi. ${ }^{16}$

Perumusan pidana pokok yang lain selain denda sebagaimana sering dirumuskan sekarang ini dalam beberapa undang-undang yang tersebar diluar KUHP, dapat saja dilakukan oleh karena menurut Barda Nawawi Arief, jenis pidana atau tindakan terhadap korporasi dapat berupa: ${ }^{17}$

a. Financial Sanction (Financial Sanction dalam hal ini misalnya denda, peningkatan pajak yang harus dibayar dan lain sebagainya)

b. Structural Sanctions

c. Restriction Entrepreneurialactivities

(Restriction Entrepreneurialactivities dalam hal ini misalnya pembatasan kegiatan usaha, pembubaran korporasi)

d. Stigmatising Sanctions

e. Mengingat korporasi atau perusahaan adalah "bisnis kepercayaan" menurut hemat penulis mengutip pendapat Brickey yang menyatakan bahwa: "...pengumuman keputusan hakim (publication), merupakan sanksi yang sangat ditakuti oleh korporasi..." nampaknya Stigmatising Sanctions dapat menjadi sanksi yang paling ditakuti oleh korporasi.

Selain berbabagai alternatif sanksi sebagaiamana telah dikemukakan diatas, menurut hemat penulis, alternatif sanksi pidana lain yang dapat

15 Barda Nawawi Arief, "Kapita Selekta Hukum Pidana", (Bandung: PT. Citra Aditya Bakti, 2010), hal. 83.

${ }^{16}$ Muladi dan Barda Nawawi Arief, Op. Cit.

17 Barda Nawawi Arief, Perkembangan Sistem Pemidanaan di Indonesia, Bahan Penataran Nasional Hukum Pidana Dan Kriminologi XI-2005, Kerjasama FH UBAYA, Forum Pemantau Pemberantasan Korupsidan ASPEK HUPIKI, di Hyat Hotel Surabaya Tanggal 14-16 Maret 2005, hal. 15. 
dibebankan terhadap korporasi adalah perampasan asset korporasi yang dilakukan baik secara pidana ataupun secara perdata.

Sebagai perbandingan, dapat dilihat pengaturan korporasi sebagai subjek hukum pidana yang dinilai dapat melakukan suatu tindak pidana dan dapat mempertanggungjawabkan perbuatannya secara pidana didalam UndangUndang No. 08 tahun 2010 tentang Pencegahan dan Pemberantasan Tindak Pidana Pencucian Uang tepatnya dalam pasal pasal 7 sampai dengan pasal 9 yang berbunyi:

Pasal 7:

(1)Pidana pokok yang dijatuhkan terhadap Korporasi adalah pidana denda paling banyak Rp. 100.000.000.000,00 (seratus miliar rupiah).

(2)Selain pidana denda sebagaimana dimaksud pada ayat (1), terhadap Korporasi juga dapat dijatuhkan pidana tambahan berupa:

a. Pengumuman putusan hakim;

b. Pembekuan sebagian atau seluruh kegiatan usaha Korporasi;

c. Pencabutan izin usaha;

d. Pembubaran dan/atau pelarangan Korporasi;

e. Perampasan aset Korporasi untuk negara; dan/atau

f. Pengambilalihan Korporasi oleh negara.

Pasal 8:

Dalam hal harta terpidana tidak cukup untuk membayar pidana denda sebagaimana dimaksud dalam Pasal 3, Pasal 4, dan Pasal 5 , pidana denda tersebut diganti dengan pidana kurungan paling lama 1 (satu) tahun 4 (empat) bulan”.

Pasal 9:

(1) Dalam hal Korporasi tidak mampu membayar pidana denda sebagaimana dimaksud dalam Pasal 7 ayat (1), pidana denda tersebut diganti dengan perampasan Harta Kekayaan milik Korporasi atau Personil Pengendali Korporasi yang nilainya sama dengan putusan pidana denda yang dijatuhkan.

(2) Dalam hal penjualan Harta Kekayaan milik Korporasi yang dirampas sebagaimana dimaksud pada ayat (1) tidak mencukupi, pidana kurungan pengganti denda dijatuhkan terhadap Personil Pengendali Korporasi dengan memperhitungkan denda yang telah dibayar.

Berdasarkan ketentuan tersebut, dapat dilihat bahwa pengaturan pidana bagi korporasi dalam Undang-Undang No. 08 tahun 2010 tidak dirumuskan secara tunggal dan dinilai jauh lebih efektif dan evisien dalam rangka memberantas tindak pidana korupsi (dan pencucian uang) jika dibandingkan 
dengan ketentuan yang ada dalam Undang-Undang No. 31 tahun 1999 sebagaimana telah diubah oleh Undang-Undang No. 20 tahun 2001 tentang Pemberantasan Tindak Pidana Korupsi. Oleh sebab itu, ketentuan-ketentuan trsebut dapat dijadikan acuan dalam merumuskan pidana pengganti denda jika denda tidak dibayar oleh korporasi.

\section{Penutup dan Kesimpulan}

Dengan diterimanya korporasi sebagai subjek hukum pidana yang dinilai dapat melakukan tindak pidana dan dapat mempertanggungjawabkannya secara pidana sudah tentu akan menimbulkan konsekuensi lain dalam penerapannya. Berbagai konsekuensi atau masalah yang dapat muncul tercermin dalam pertanyaan dapatkan pidana mati atau pidana penjara sebagaimana diatur dalam pasal 10 KUHP diterapkan terhadap suatu korporasi? Atau apakah "corporate death penalty" dan "corporate imprisonment" sebagaimana dikemukakan oleh Brickey dapat dikatakan sebagai penjatuhan pidana mati atau pidana penjara bagi suatu korporasi? Apabila dibandingkan dengan ketentuan yang ada dalam Undang-Undang No. 31 tahun 1999 sebagaimana telah diubah oleh Undang-Undang No. 20 tahun 2001 tentang Pemberantasan Tindak Pidana Korupsi tepatnya dalam pasal 2 ayat (2) dan pasal 18 ayat (1) poin $\mathrm{c}$ dan poin $\mathrm{d}$ Undang-Undang ini maka menurut hemat penulis, pada dasarnya "corporate death penalty" sebagaimana dikemukakan oleh Brickey sama dengan ketentuan "penutupan seluruh atau sebagian perusahaan" dan "corporate imprisonment" pada dasarnya sama dengan ketentuan "pencabutan seluruh atau sebagian hak-hak tertentu atau penghapusan seluruh atau sebagian keuntungan tertentu" sebagaimana diatur dalam pasal 18 ayat (1) poin c dan poin d Undang-Undang ini. Selain itu, apabila melihat ketentuan dalam pasal 2 ayat (2) yang menyatakan bahwa: "Dalam tindak pidana korupsi sebagaimana dimaksud dalam ayat (1) dilakukan dalam keadaan tertentu, pidana mati dapat dijatuhkan". Dan apabila dilihat dari penjelasannya diatur bahwa: "yang dimaksud dengan "keadaan tertentu" adalah apabila tindak pidana tersebut dilakukan terhadap dana-dana penanggulangan bagi penaggulangan keadaan bahaya, bencana alam nasional, penanggulangan terhadap akibat kerusuhan sosial yang meluas, penanggulangan krisis ekonomi, dan terjadi pengulangan tindak pidana korupsi". Oleh karena itu, menurut hemat penulis, "corporate death penalty" sebagaimana dikemukakan oleh Brickey diatas dapat pula diartikan sebagai penjatuhan pidana mati dalam arti yang sesungguhnya (apabila dikonstruksikan terhadap korporasi akan menjadi penutupan seluruh korporasi) bagi suatu korporasi yang melakukan tindak pidana korupsi dalam keadaan dan terhadap dana-dana penanggulangan bagi penaggulangan keadaan bahaya, bencana alam nasional, penanggulangan terhadap akibat kerusuhan sosial yang meluas, penanggulangan krisis ekonomi, dan terjadi pengulangan tindak pidana korupsi. Selain itu, dengan adanya terminologi "dapat" maka pelaksanaan penjatuhan pidana mati bagi korporasi ini bukan menjadi suatu keharusan melainkan suatu alternatif sanksi. Terkait dengan hal ini, menurut hemat penulis, pengaturan penjatuhan pidana mati bagi korporasi sudah tepat 
dan dapat dilaksanakan atau diterapkan apabila memang sangat-sangat mendesak dan dijatuhkan sebagai pemeberatan atau unsur yang memberatkan pidana (gequaliviceerde).

Apabila pembaca masih berfikir konfensional/tradisional atau masih berfikir bahwa penjatuhan pidana penjara atau pidana mati tidak dapat diterapkan terhadap suatu korporasi maka sanksi pidana yang dapat diterapkan terhadap korporasi hanya pidana denda. Apabila pidana denda ini diterapkan terhadap orang sudah tentu tidak akan menimbulkan masalah karena apabila pidana denda tidak dibayar maka dapat digantikan oleh pidana kurungan pengganti denda. Lain halnya apabila pidana denda ini dijatuhkan terhadap suatu korporasi, apakah dapat diterapkan pidana kurungan pengganti denda? Apabila pembaca masih berfikiran tradisional sudah tentu jawabannya adalah tidak dan itu artinya apabila pidana denda tidak dibayar oleh korporasi maka tidak ada alternatif sanksi lain yang dapat dijatuhkan terhadap korporasi.

Demikian juga dengan jenis pidana tambahan sebagaimana diatur dalam pasal 10 poin $\mathrm{b}$ angka 1 KUHP tentang pencabutan hak-hak tertentu (yang penjabarannya diatur dalam pasal $35 \mathrm{KUHP}$ ) dan pasal 10 poin b angka 2 tentang perampasan barang-barang tertentu (yang penjabarannya diatur dalam pasal 39 KUHP) tidak dapat diterapkan terhadap korporasi. Oleh sebab itu dapat disimpulkan bahwa perumusan sanksi pidana yang dapat diterapkan terhadap korporasi dirumusakan secara tunggal yaitu pidana denda dan tidak ada alternative lain apabila pidana denda tersebut tidak dibayar oleh korporasi (baik yang diatur dalam KUHP ataupun yang diatur diluar KUHP). Oleh sebab itu, dalam kebijakan hukum pidana (Criminal Penal Policy) yang akan dating sebaiknya sanksi pidana yang dapat dijatuhkana terhadap korporasi tidak dirumuskan secara tunggal melainkan dirumuskan alternative sanksi pidana lain misalnya "corporate death penalty" atau "corporate imprisonment" sebagaimana dikemukakan oleh Brickey diatas. Atau jenis sanksi lain seperti Penutupan seluruh atau sebagian perusahan si terhukum untuk waktu tertentu dan Pencabutan seluruhnya atau sebagian fasilitas-fasilitas tertentu yang telah atau dapat diperolehnya dari pemerintah oleh perusahan selama waktu tertentu atau bahkan penempatan perusahan di bawah pengampuan selama waktu tertentu seperti yang dikemukakan oleh Suprapto. Atau jenis saksi pidana berupa Financial Sanction (Financial Sanction dalam hal ini misalnya denda, peningkatan pajak yang harus dibayar dan lain sebagainya), Structural Sanctions, Restriction Entrepreneurialactivities (Restriction Entrepreneurial activities dalam hal ini misalnya pembatasan kegiatan usaha, pembubaran korporasi), Stigmatising Sanctions, pengumuman keputusan hakim (publication) yang merupakan sanksi yang sangat ditakuti oleh korporasi seperti yang dikemukakan oleh Barda Nawawi Arief diatas. Kemudian, mengingat korporasi atau perusahaan adalah "bisnis kepercayaan" menurut hemat penulis mengutip pendapat Brickey yang menyatakan bahwa: “...pengumuman keputusan hakim (publication), merupakan sanksi yang sangat ditakuti oleh korporasi..." nampaknya Stigmatising Sanctions dapat menjadi sanksi yang paling ditakuti oleh korporasi. Selain itu, menurut hemat penulis, alternatif sanksi pidana lain yang dapat dibebankan terhadap korporasi 
adalah perampasan asset korporasi yang dilakukan baik secara pidana ataupun secara perdata. 


\section{Daftar Pustaka}

Arief, Barda Nawawi. Kapita Selekta Hukum Pidana, Bandung: PT. Citra Aditya Bakti, 2010.

Perkembangan Sistem Pemidanaan di Indonesia, Bahan Penataran Nasional Hukum Pidana Dan Kriminologi XI-2005, Kerjasama FH UBAYA, Forum Pemantau Pemberantasan Korupsi dan ASPEK HUPIKI, di Hyat Hotel Surabaya Tanggal 14-16 Maret 2005.

Gillies, Peter. (Penyunting: Barda Nawawi Arief), Criminal Law, 1990.

Loqman, Loebby. Kapita Selekta Tindak Pidana Dibidang Perekonomian, Jakarta: Dtacom, 2002.

Muladi dan Dwidja Priyatno, Pertanggungjawaban Korporasi Dalam Hukum Pidana, Bandung: STHB, 1991.

Muladi dan Barda Nawawi Arief, Bunga Rampai Hukum Pidana, Bandung: Alumni, 2007.

Setiyono, H. Kejahatan Korporasi Analisis Viktimologi Dan Pertanggungjawaban Korporasi Dalam Hukum Pidana, Edisi kedua Cetakan pertama, Malang: Banyumedia Publishing, 2003. 